December 2009

\title{
Should President Omar al-Bashir of Sudan Be Charged and Arrested by the International Criminal Court?
}

Alex de Waal

Gregory H. Stanton

Follow this and additional works at: https://digitalcommons.usf.edu/gsp

\section{Recommended Citation}

de Waal, Alex and Stanton, Gregory H. (2009) "Should President Omar al-Bashir of Sudan Be Charged and Arrested by the International Criminal Court?", Genocide Studies and Prevention: An International Journal: Vol. 4: Iss. 3: Article 5.

Available at: https://digitalcommons.usf.edu/gsp/vol4/iss3/5

This Articles is brought to you for free and open access by the Open Access Journals at Digital Commons @ University of South Florida. It has been accepted for inclusion in Genocide Studies and Prevention: An International Journal by an authorized editor of Digital Commons @ University of South Florida. For more information, please contact digitalcommons@usf.edu. 


\title{
Book Review
}

\section{Samuel Totten and Eric Markusen, eds., Genocide in Darfur: Investigating the Atrocities in the Sudan. New York: Routledge, 2006. Pp. 334, paper. $\$ 37.95$ US.}

\author{
Reviewed by Justyna Klaczany, Jagiellonian University, Cracow, Poland; Silesian \\ University, Katowice, Poland
}

Edited by the two prominent genocide scholars Samuel Totten and Eric Markusen, Genocide in Darfur: Investigating the Atrocities in the Sudan is an outstanding collection of essays that describes in great detail the genesis, design, implementation, results, and ramifications of the Darfur Atrocities Documentation Project (ADP). What makes this work significant is the fact that the essays are written not only by many noted scholars, US government and non-governmental organization officials, but also by the ADP designers and investigators. The perspectives of the latter is extremely valuable, since they were the people who conducted the interviews with the Darfur refugees in the internally displaced camps (IDP) in Chad and who listened to the victims' first-hand accounts of the horrific experiences they suffered at the hands of the Government of Sudan (GoS) troops and the Janjaweed (Arab militia).

The book consists of fourteen chapters grouped into five parts: (1) "The Background on Darfur," (2) "The Investigation," (3) "The Genocide Determination," (4) "The Significance of the Darfur Atrocities Documentation Project: A Precedent for the Future? The Perspective of 'Outsiders," and (5) "Analysis of the Rationale and Reasoning Behind the U.S. ADP and Genocide Determination." In addition, the editors have included a very useful chronology of the Darfur crisis and five noteworthy appendices: "The Darfur Refugee Questionnaire," which is very informative, especially for those interested in the research tools used in the project; the summary of the ADP final report; US Secretary of State Colin L. Powell's testimony before the Senate Foreign Relations Committee, in which he announced that "genocide has occurred in Darfur and may still be occurring"; the United Nations Convention on the Prevention and Punishment of the Crime of Genocide; and a list of the personnel involved in the ADP.

The book begins with a historical overview of Darfur that begins with the establishment of the Fur sultanate in 1650 and concludes in 2004 when the efforts of the international community to address the "worst humanitarian crisis" started. Robert O. Collins, a noted expert on the history of Sudan and the author of many widely acclaimed books including Africa's Thirty Years War: Chad, Libya and the Sudan, 19631993, focuses on the complex root causes of the conflict such as marginalization of the region, the tribes' struggles for resources, and the ethnic tensions between different tribes exacerbated by the "cynical and dysfunctional Islamist government of the Sudan." Although this chapter demands a lot of concentration on the part of the reader as the text is full of historical data, it enables non-experts to understand the complexity of the crisis.

Part 1 also includes a chapter by Andrew S. Natsios, who, at the time of the investigation, was the chief administrator of the US Agency for International Development 
(USAID). After briefly presenting the reasons for American involvement in the Sudan, the context of the crisis in Darfur and the atrocities committed by the Janjaweed and GoS military, he focuses on the actions taken by USAID to address the crisis, which included providing humanitarian aid, conducting research and providing data such as satellite imagery of the situation in Darfur to high level members of the US government and to the members of the UN Security Council. Finally, Natsios explains the genesis and significance of the ADP.

Part 2 is entirely devoted to a description of the Darfur ADP. Each of its chapters focuses on a different aspect of the investigation. In chapter 3, Nina Bang-Jensen and Stefanie Frease, leaders of the Coalition of International Justice, the latter of which was selected by the State Department to plan and implement the ADP, describe the stages of the project from its creation after the meeting of NGOs at the US State Department in Washington in late June 2004, through assembling the team of investigators, dispatching the assessment team and the field investigators to Chad, to their safe return home at the end of August. They make the reader aware of the fact that the ADP was a logistical challenge, as well as a dangerous enterprise fraught with innumerable difficulties. In conclusion, they state, "For those who heard firsthand from over twelve hundred refugees about their similarly harrowing accounts of attacks, murder, rape, racial epithets, and destruction of their way of life, it was gratifying to know their voices had been heard, at least by some" (57).

In turn, Jonathan P. Howard, a research analyst with the US State Department, provides an in-depth report of the development of the research methodology. The importance of this research and its purpose forced the methodologists to design it in such a way that it would ultimately provide statistically significant and reliable data obtained from a representative sample. Although the detailed description of the questionnaire design, data entry, and analysis may not be interesting for non-experts, it is worthwhile reading for those who have any doubts concerning the validity and reliability of the project. The author presents, in a very clear way, the quantitative findings that shed light on the scale and nature of human suffering in Darfur.

The chapter written by Helge Niska, an expert on community interpreting services and interpreter training, provides an insight into the essential role of interpreters, a role which is unfortunately very often underestimated. He addresses a host of issues such as the recruitment, testing, and training of the interpreters. This chapter is a very important contribution to the volume because Niska points out the essential role interpreters have in international research and that the lack of proper training can lead to serious distortions in the results.

In contrast to the earlier chapters in this part, which to a large extent deal with technical details of the preparation of the ADP, Samuel Totten and Eric Markusen's chapter provides a detailed account of the interviewers' work on the ground. It includes detailed and moving reflections and stories by members of the ADP team. As far as this reviewer is concerned, this is one of the most important essays in the entire volume. It is here that the reader learns about the horrific experiences of the victims. Unlike other chapters, in which the ADP findings are summarized by means of diagrams and percentages, this chapter, through the reflections of different investigators, presents stories of individual human beings who have a name and who experienced enormous suffering, which is all but unimaginable to most people in the Western world.

Tellingly, the chapter shows that what was most difficult for the investigators were not the harsh conditions on the ground in Chad and logistical challenges, but conducting the interviews. As Markusen puts it: "For me personally, the most heart- 
wrenching aspect of this mission was asking the respondents for details of their murdered relatives-spouses, children, parents, cousins, aunts, uncles. Many lost four or five or more relatives, and recording names, ages, gender, relationship, and cause of death left me emotionally exhausted" (90).

Notably, this chapter concludes with the investigators' bitter comments on the lack of action from the international community. Debbie Bodkin, a Canadian police officer and one of the ADP investigators, acknowledges, "My heart breaks knowing that even though our work was successful in many ways, the horrors are still continuing now as I write this" (107). Samuel Totten adds, "If the international community continues to waver and equivocate, there is no doubt in my mind that ten years from now the international community will apologize to the victims of Darfur just as it did recently to the Tutsis on the tenth anniversary of the 1994 Rwandan genocide. But such apologies are as hollow as they get when something could have and should have been done to save the people in the first place" (107). The strongest statement on the reasons for inaction comes from Vanessa Allyn, who asserts:

I also feel that the reliance on the AU [African Union] troops as some sort of piecemeal solution is an excuse to do less ... It seems to come down to the same old racist/ colonialist international attitude towards the "dark" continent: "It is an African problem, let the Africans solve it, and if they don't solve it, the people who are dying are just Africans anyway. Let them go on slaughtering each other until they learn their lesson or all die, but we aren't going to waste our precious western resources or lives on something like hopeless, chaotic Africa." (106)

In Chapter 7, which opens the third part of the book, Stephen A. Kostas discusses aspects of the determination of genocide. He does so based on interviews that he conducted together with Eric Markusen, Pierre-Richard Prosper (former US Ambassadorat-Large for War-Crimes), and Lorne Craner (former Assistant Secretary for the State Department's Bureau of Democracy, Human Rights and Labor). Kostas explains the US State Department's motives for the creation of the ADP and the subsequent genocide determination. The text is very engaging, especially when Kostas reports on the analysis of the data obtained by the ADP. The author describes how the State Department concluded that genocidal intent, which is the most debatable issue, could be inferred from the evidence. Although Kostas provides the reader with an in-depth analysis of how the determination of genocide is made, one question remains: Why was US government's action reduced only to calling on the UN under Article VIII?

This vacuum is partly filled by Jerry Fowler, who elaborates on the legal definition of genocide. In order to answer this question he zeroes in on two reasons. First, he sees the problem in the UN Convention on the Prevention and Punishment of the Crime of Genocide (the Genocide Convention) itself, when he rightly comments: "After calling for international cooperation 'to liberate mankind from such an odious scourge' the Convention proceeds to define the crime of genocide in terms that, from the perspective of 'preventing' or 'suppressing' genocide, are problematic. It then offers only the vaguest sense of what should be done when genocide is imminent or actually underway" (127). This is accomplished by a thorough analysis of the conclusions reached by the US government and the UN Commission of Inquiry (COI). In doing so, Fowler presents convincing arguments when he criticizes the COI's final report.

The second reason for inaction was the lack of political will. Fowler gets to the core of this problem when he concludes that

the prevention and suppression of genocide and other mass atrocities will never be accomplished by the international community or members of that community through 
a sense of legal obligation. It will happen, if at all, as a result of political or practical necessity. Only by recognizing and acting on this reality is there hope for ending the heartbreaking irony of a universally condemned crime that is allowed to transpire in broad daylight. (138)

Ultimately, for those interested in the Darfur genocide, Fowler's powerful and passionately critical analysis is a must.

Part 3 concludes with a chapter entitled "Prosecuting Gender Crimes Committed in Darfur: Holding Leaders Accountable for Sexual Violence" by Kelly Dawn Askin, an expert on international criminal law, international humanitarian law, and gender justice. The text is not an easy read and that is for two basic reasons. First, the author, drawing from the data obtained by the ADP, describes in minute detail the sexual violence in Darfur. Reading about such horrific crimes is simply heartbreaking. Second, the section of this chapter, in which the questions of responsibility and accountability of the perpetrators are analyzed on the basis of examples from the ICTR and ICTY judgements, is very demanding for non-experts because of the complex legal terms Askin uses. Nevertheless, this chapter is well documented and surely contributes to the better understanding of the complex issues related to prosecuting not only the physical perpetrators of sexual violence but also the leaders who have a duty to protect the civilian population from such crimes.

Part 4 consists of short but very thought-provoking chapters that are devoted to the analysis of the significance of the ADP and the evaluation of the international community's actions-and especially those of the United States-to end the crisis. Taylor B. Seybolt stresses that the ADP is a precedent for the future as it proved that it is possible to identify a genocide in time to stop it, but he criticizes the US government for inaction and claims: "The Bush administration's declaration of genocide has proved to be a substitute for action, not a call to action." Continuing, he asserts: "Sadly, the lack of action should not surprise us. Governments are most likely to act when they perceive threats to their primary interests or an opportunity to promote their primary interests. When secondary or tertiary interests are at stake, we can expect to see only weak responses, especially when taking action involves risks" (168). Ultimately, Seybolt draws a pessimistic, but, unfortunately, correct conclusion: "The most troubling aspect of the rhetoric in Washington is that governments with the power to act now understand that it is acceptable to allow mass killing even when they cannot deny knowledge of it" (168-169).

In his essay entitled "From Rwanda to Darfur: Lessons Learned?" Gerald Caplan is even more critical than Seybolt. The value of this chapter lies not only in what is said but also in how it is said. Caplan uses very strong language and the text is filled with trenchant comments. He points to three lessons that emerged from the international community's failure in Rwanda. First, the international community will only take serious and effective action when its political interests are involved. Second, any time "another Rwanda" appears on the horizon, if it garners enough attention then the international community would be inclined to act for it could not plead ignorance of the event. Third, “[US President Bill] Clinton's position that there was no fullblown genocide in Rwanda unwittingly provided the glimmer of hope [that] if Rwanda was 'not quite' a genocide, and therefore intervention was not obligatory, it surely followed logically that if a genocide were declared in the future" (175), the international community would commit to intervening in a timely and effective manner. Caplan argues that the last two conditions were fulfilled in Darfur, and then bitterly concludes: "From the point of view of the hopes raised by two of the optimistic lessons from Rwanda, the response of the 'international community' to the crisis in Darfur 
can only be considered a giant, tragic set-back. It is not too much to say that Darfur shows that only the first despairing lesson-the bottomless cynicism and self-interest of the major powers-remains valid, while the hopes have been largely destroyed" (176). To continue to summarize Caplan's chapter will only "kill the spirit" of his text. Suffice it to say that it is imperative to read this essay.

Next, Gregory H. Stanton provides a legal analysis of the concept of genocide and elaborates on the reasons why this term applies to the crimes committed in Darfur. He argues that they are genocide as defined by the UN Genocide Convention because "[t]he atrocities are intentional, evidenced by the systematic nature of their destruction ..., the crimes are directed against groups protected by Genocide Convention ..., the crimes include all the acts of genocide enumerated in the Genocide Convention ..." (183).

Stanton concludes that the reluctance to apply the appellation of genocide to Darfur has its source in the misconception that the Genocide Convention contains a legal obligation to act, that only destruction in whole constitutes genocide, and that motive and intent are the same thing. In doing so, Stanton provides clear and logical arguments to support his interpretation.

In contrast, there are and will be other legal experts who will argue that atrocities in Darfur are not genocide. Scott Straus, in the closing essay of part 4, who supports the view presented by Jerry Fowler, underscores that the main cause of these endless debates is the Genocide Convention itself. He stresses that disambiguating the concept is a prerequisite for effective genocide prevention. In his conclusion, he enumerates the same reasons for the international community's inaction in Darfur as those expressed by most of the contributors in this volume. However, he adds that the most important factor is the politics within the Security Council, whose two permanent members-Russia and China-have blocked any forceful action.

In the last essay in this volume, Samuel Totten evaluates the ADP, confronts and successfully refutes criticism of this project made by other scholars, such as Alex de Waal and Howard Adelman, and assesses the US government's policy on Darfur. Totten, on the one hand, effectively recapitulates what had been said, and, on the other hand, complements the whole work by explaining the reasons for such US policy on Darfur and by providing an objective critique of this policy. In doing so, he presents not only strengths but also certain weaknesses of the ADP. In confronting criticism, he uses very convincing arguments and poses thought-provoking questions. Totten is successful in showing the positive consequences of $\mathrm{ADP}$ and the genocide determination, but, at the same time, on numerous occasions, he expresses strong criticism concerning the lack of meaningful action on the part of the US government, which is reflected in the following statement: "The point is, though, there is plenty that the United States could have done-and still can and should do-but it hasn't. And that is nothing short of shameful" (220).

Throughout the book, various authors stress the importance of the ADP and how the genocide determination constituted "the first official investigation by a sovereign nation of an ongoing case of mass violence for the express purpose of determining whether or not the violence amounted to genocide ..., the first time that one government formally accused another government of ongoing genocide ..., and the first time that Chapter VIII of the UN Convention on the Prevention and Punishment of the Crime of Genocide was invoked calling on the Security Council to take action" (xiv). Because of these reasons, as well as others cited in this review, Genocide in Darfur is an extremely important contribution to the literature on Darfur and especially on genocide, particularly because it provides an in-depth analysis of these important 
events and issues. What is more, because these events and issues are analyzed from different perspectives, readers are provided with a lot of food for thought. All contributors convey their ideas in a very logical and clear way, so even a non-expert can gain insight into the complexity of the issue of genocide in international relations.

Ultimately, each author seems to agree with the statement made by Jan Pfundheller, one of the ADP investigators: "I heard it [the account of the horrors] from the victims themselves. And having heard it, knowing in my heart that I can and will stand up and say 'this happened' to whoever will listen, to whoever cares, and to those who do not. To give a louder voice to the victims and their horrific truths" (106). 